ON BEING AND COGNITION 


\title{
2.
}

MEDIEVAL PHILOSOPHY

Texts and Studies

Gyula Klima

series editor

\author{
Richard Cross \\ Brian Davies \\ Peter King \\ Brian Leftow \\ John Marenbon \\ Giorgio Pini \\ Robert Pasnau \\ Richard Taylor \\ Jack Zupko \\ editorial board
}




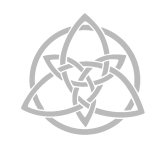

\section{ON BEING}

AND COGNITION

Ordinatio 1.3

JOHN DUNS SCOTUS

Edited and translated by John van den Bercken 
Copyright (C) 2016 Fordham University Press

All rights reserved. No part of this publication may be reproduced, stored in a retrieval system, or transmitted in any form or by any means-electronic, mechanical, photocopy, recording, or any otherexcept for brief quotations in printed reviews, without the prior permission of the publisher.

Fordham University Press has no responsibility for the persistence or accuracy of URLs for external or third-party Internet websites referred to in this publication and does not guarantee that any content on such websites is, or will remain, accurate or appropriate.

Fordham University Press also publishes its books in a variety of electronic formats. Some content that appears in print may not be available in electronic books.

Visit us online at www.fordhampress.com.

Library of Congress Cataloging-in-Publication Data

Names: Duns Scotus, John, approximately 1266-1308, author. | Bercken, John van den, editor.

Title: On being and cognition : Ordinatio 1.3 / John Duns Scotus ; edited and translated by John van den Bercken.

Other titles: Ordinatio. 1.3. English

Description: New York, NY : Fordham University Press, 2016. | Series: Medieval philosophy: texts and studies | Includes bibliographical references.

Identifiers: LCCN 2015042266 (print) | LCCN 2016008050 (ebook) | ISBN 9780823270736 (cloth : alk. paper) | ISBN 9780823270750 (ePub)

Subjects: LCSH: Ontology-Early works to $1800 . \mid$ Individuation-Early works to 1800 .

Classification: LCC B765.D72 E5 2016 (print) | LCC B765.D72 (ebook) | DDC 121-dc23

LC record available at http://lccn.loc.gov/2015042266

Printed in the United States of America

$\begin{array}{llllllll}18 & 17 & 16 & 5 & 4 & 3 & 2 & 1\end{array}$

First edition 